\title{
Psychological status and breath at children with psychosomatic pathology
}

\author{
Oleg Grishin, Ekaterina Paramoshkina*, Varvara Leshinskaya \\ From $1^{\text {st }}$ International Congress on Neurobiology and Clinical Psychopharmacology and European \\ Psychiatric Association Conference on Treatment Guidance \\ Thessaloniki, Greece. 19-22 November 2009
}

\section{Background}

Breath and emotions are closely connected and that is reflected in various symptomatology in children with psychosomatic pathology. The aim of study was to estimate the psychosomatic status and ventilation function of breath using of respiratory biofeedback in children with various psychosomatic diseases.

\section{Materials and methods}

To examine the relationship between respiration and psychological status in children with psychosomatic disorders, 20 children aged 8-12 were studied during the integrated treatment using respiratory BFB by capnography at day-care hospital. Rates of respiratory function, anxiety level and frustration reactivity were measured.

\section{Results}

The significant decreases of anxiety level, combined with an increase in frustration tolerance, were found. Moreover, these processes were accompanied by an increase in $\mathrm{CO} 2$ at the end of exhalation (FetCO2) and the structure changes of breathing pattern. An internal restructuring of the respiratory cycle was observed: expiration time increased while the respiration rate remained unchanged.

\section{Conclusions}

Whereas hyperventilation syndrome diagnosis in children should be focused mainly on FetCO2 and respiration rate indices, to identify other forms of functional respiratory disorders it is necessary to control the respiratory cycle data, among them the exhalation duration particularly.

Laboratory for respiratory physiology, Research Institute of Physiology SB RAMS, Novosibirsk, Russia
Published: 22 April 2010

doi:10.1186/1744-859X-9-S1-S127

Cite this article as: Grishin et al:: Psychological status and breath at children with psychosomatic pathology. Annals of General Psychiatry 2010 9(Suppl 1):S127.
Submit your next manuscript to BioMed Central and take full advantage of:

- Convenient online submission

- Thorough peer review

- No space constraints or color figure charges

- Immediate publication on acceptance

- Inclusion in PubMed, CAS, Scopus and Google Scholar

- Research which is freely available for redistribution

Submit your manuscript at www.biomedcentral.com/submit
C Biomed Central 